\title{
Effectiveness of i-Kasih Module as Support to the Families of Opiat Addicts in Rehabilitation
}

Farah Syazrah Mohd Ghazalli, Norizan Abdul Ghani, Wan Mohd Yusof Wan Chik, Abdul Wahab Md Ali, Berhanundin Abdullah, Zulkifli Mohd \& Abdullah Alqari Mohd Zabudin

To Link this Article: http://dx.doi.org/10.6007/IJARBSS/v11-i11/11551

DOI:10.6007/IJARBSS/v11-i11/11551

Received: 09 September 2021, Revised: 11 October 2021, Accepted: 27 October 2021

Published Online: 02 November 2021

In-Text Citation: (Ghazalli et al., 2021)

To Cite this Article: Ghazalli, F. S. M., Ghani, N. A., Chik, W. M. Y. W., Ali, A. W. M., Abdullah, B., Mohd, Z., \& Zabudin, A. A. M. (2021). Effectiveness of i-Kasih Module as Support to the Families of Opiat Addicts in Rehabilitation. International Journal of Academic Research in Business and Social Sciences, 11(11), 524 534.

Copyright: (c) 2021 The Author(s)

Published by Human Resource Management Academic Research Society (www.hrmars.com)

This article is published under the Creative Commons Attribution (CC BY 4.0) license. Anyone may reproduce, distribute, translate and create derivative works of this article (for both commercial and non-commercial purposes), subject to full attribution to the original publication and authors. The full terms of this license may be seen

at: http://creativecommons.org/licences/by/4.0/legalcode

Vol. 11, No. 11, 2021, Pg. $524-534$

Full Terms \& Conditions of access and use can be found at http://hrmars.com/index.php/pages/detail/publication-ethics 


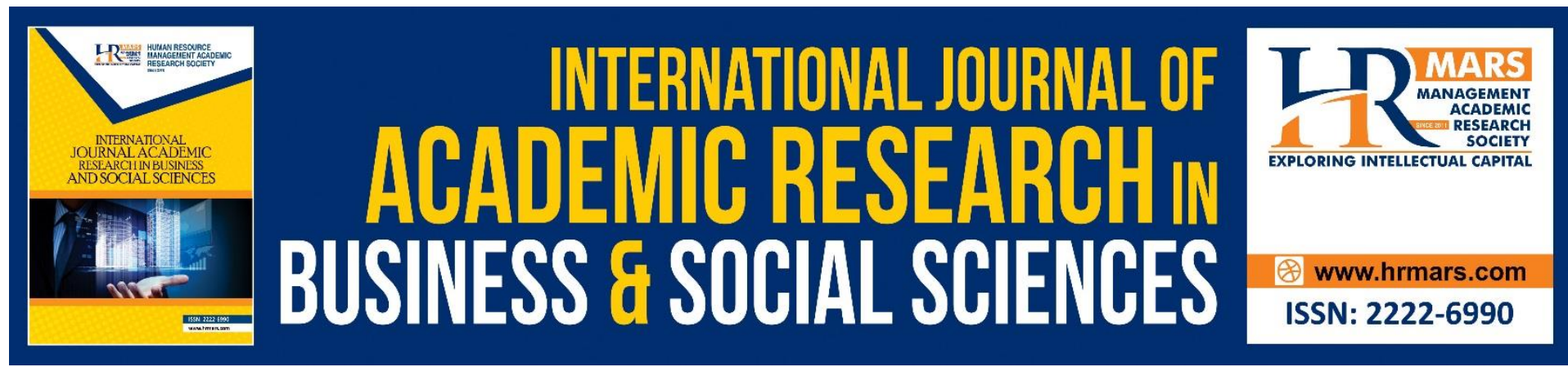

\title{
Effectiveness of i-Kasih Module as Support to the Families of Opiat Addicts in Rehabilitation
}

\section{Farah Syazrah Mohd Ghazalli ${ }^{1}$, Norizan Abdul Ghani ${ }^{2}$, Wan Mohd Yusof Wan Chik ${ }^{3}$, Abdul Wahab Md Ali ${ }^{1}$, Berhanundin Abdullah $^{3}$, Zulkifli Mohd ${ }^{3} \&$ Abdullah Alqari Mohd Zabudin ${ }^{3}$}

${ }^{1}$ Pusat Pengajian Teras, Universiti Sultan Zainal Abidin, Terengganu, Malaysia, ${ }^{2}$ Fakulti Sains Sosial Gunaan, Universiti Sultan Zainal Abidin, Terengganu, Malaysia, ${ }^{3}$ Institut Penyelidikan

Produk dan Ketamadunan Melayu Islam, Universiti Sultan Zainal Abidin, Terengganu, Malaysia, ${ }^{4}$ Fakulti Pengajian Kontemporari Islam, Universiti Sultan Zainal Abidin,

Terengganu, Malaysia

Email: norizabd@unisza.edu.my

\begin{abstract}
Recovery of opiate addiction is lifelong, involving physical, psychological and spiritual aspects. Physical rehabilitation is closely linked to clinical treatment while psychological and spiritual require external support such as family support. Family involvement in assisting rehabilitation is always an issue when not many families have the specific expertise to assist in rehabilitation, especially for addicts undergoing rehabilitation outside the institution. The objective of this module is to discuss the construction of the i-Kasih module as a support to the families of opiate addicts and evaluate the effectiveness of the i-Kasih module on family social support. The methodology used is a quantitative method, data was collected through a questionnaire on 35 participants in Kuala Terengganu who successfully followed the i-Kasih module fully. This module is spiritually based and is divided into six module units. All units of this module have different focuses such as the concept of a prosperous family according to Islam, forms of social support, psychology of da'wah and clinical and Islamic treatment approaches. The i-Kasih module, which is built on the experiences and needs of the families of addicts, is able to help increase social support for the families of opiates. Therefore, this module has the potential to be implemented to families with similar problems so that families are able to increase support throughout the recovery of opiate addicts.
\end{abstract}

Keywords: Family Module, Addiction Recovery, Opiate Addict, Addict Family, Opiate

\section{Introduction}

Opiates are a group of drugs consisting of heroin, morphine, codeine, opium and methadone while addiction refers to physical and mental dependence on drugs including opiates (ACREDA, 2014). Recovery of opiate addiction is a lifelong process, involving physical, psychological and spiritual aspects. Physical rehabilitation is closely related to clinical treatment while psychological and spiritual requires external support such as family support (Fauziah \& Kumar, 2009). Drug rehabilitation programs including opiates often suggest that 
family has an important role in prevention from the beginning. This is because the family as a sub-community plays a role as a socialization agent to their respective family members.

Family social support is a form of assistance provided by the family to opiate addicts involving both internal and external aspects. These aspects are needed to drive more effective and comprehensive recovery. Previous studies have shown family support has a significant relationship in aiding recovery not only of drug addiction but also in various types of health care (Khadijah et al., 2011; Snap et al., 2015; Luther, 2015). For drug rehabilitation cases, previous studies have shown that the strength of family social support strengthens the self acceptance of addicts as well as facilitates communication between families and addicts (Ruhani et al., 2012; Afandi et al., 2009; Fauziah et al., 2014).

In Malaysia, rehabilitation is more concentrated in institutions, where programs and modules are run by trained officers over a period of time. Addicts who follow rehabilitation programs and receive family support show higher recovery rates than addicts who do not receive family support (Rafaei, W. et al., 2009). However, the increase in relapse cases recorded in the statistics report of the National Anti Drug Agency (AADK) raises questions about the effectiveness of rehabilitation programs. Addicts in who followed rehabilitation on legal provisions were more likely to relapse than addicts who followed methadone rehabilitation voluntarily. The impact of rehabilitation programs in institutions was found to be less encouraging to all addicts, due to the influence of individual personalities. Community-based voluntary rehabilitation treatment options are an alternative to this issue, yet they have to face constraints such as legal provisions and implementation of existing policies, lack of skilled manpower and infrastructure, widespread stigma and differences in modules used (Adeeba \& McBrayer, 2015).

Community -based rehabilitation requires the family to act as the core strength in-line with the family's role and relationship with the opiate addict. The various rehabilitation modules used today are more focused on individuals addicted to drugs or opiates, while the needs of the family are given less attention. Family involvement in rehabilitation assistance is always an issue when not many families are involved in rehabilitation assistance, especially for addicts undergoing rehabilitation outside the institution. In fact, addicts who successfully quit addiction while in institution, fail to pursue rehabilitation outside due to lack of family support.

Supportive failure is often associated with the family environment. The failure of communication in the family causes support to fail to be given as it is influenced by stigma and media influence. This makes parents afraid to talk because they consider drugs to be a taboo subject. Families who take the attitude of "waiting for the right time" are also a source of support often failing to be given (Schafer, 2011; Saedah et al., 2008). The family burden in managing addicts take many forms. Emotional burdens occur when families have to bear feelings of shame, depression, anger, frustration and worry. The economic burden occurs when addicts lose their jobs due to addiction and have to depend on their families for expenses. Meanwhile, another burden is conflict stemming from frustration in family relationships. Family instability leads to abuse and neglect of the responsibilities of other family members. This burden has also influenced family reactions and behaviors towards 
addicts to the point of becoming a barrier to family social support throughout the recovery process (Daley, 2013).

On the other hand, many families want to help with recovery but faced knowledge constraints. For opiate addiction, methadone treatment has been introduced in Malaysia since 2005. However, families still do not understand the process that opiate addicts have to go through when receiving methadone treatment. A study by Azinur, Noriah and Nursyuhadah (2013) found that family understanding of Methadone Retention Therapy in Malaysia is still at a low level where $65 \%$ of respondents have little information and another $35 \%$ do not realize the importance of the program. Family attitudes are also an issue where the family's desire to help the addict however turns into a enabling the addiction. The attitude of codependency and enabler was initially an effort to help the recovery process, ended up encouraging addicts to feel comfortable being enabled to a point that they refuse to recover. While the facilitator (enabler) is the family attitude provides facilities to protect addicts from being affected more severely due to addiction. Both of these attitudes drive families to ignore self-needs leading to stress and emotional dependence on the addict's self-situation (NOVA, 2016).

Families face more internal family challenges compared to external family challenges (Syazrah, et al., 2018). It is therefore difficult for families to meet the rehabilitation needs of addicts while the family has unmet needs (Sullivan et al., 2002). In fact, many rehabilitation modules focus on the needs of addicts and only involve families in a few activities.

Catalysed from this need, the i-Kasih module is designed to meet the needs of addicts' families so that families can support the rehabilitation efforts undertaken by addicts outside the institution. The content of the module emphasizes spiritual element, in accordance with the background of the community in Terengganu whose majority is Muslim. In fact, based on an initial survey in the field, the families had stated the rehabilitation strategies that the families had implemented focused on alternative treatments related to the spiritual element. Therefore, this spiritual element was chosen to be the main theme of the module, in line with the tendencies of the community on the East Coast Malaysia.

In Islamic law, there are several things to note regarding the drug rehabilitation process. The first is a solid foundation of faith. For example through an understanding of the concept of sin and reward. (Miharlina, 2010). In addition, the study of Miller \& Thoresen (2003) gave emphasis to the spiritual element for which there is scientific evidence about the role of spiritual element in the process of addiction recovery. In the process of drug rehabilitation, without a strong religious foundation such as a lack of spiritual practice, the level of substance abuse will increase (Sterling et al., 2007). Therefore, in human life spirituality is seen to be able to be an alternative as a deterrent in order not to get involved with addiction (Gomes et al., 2013). In Malaysia, many rehabilitation practitioners have begun to take spirituality or psychospiritual as a key element of rehabilitation especially in dealing with family-related issues suffering from psychological problems and trauma (Malik, n.d).

More specifically, the process of drug rehabilitation in Islam also emphasizes the element of empowerment in the families of addicts. Hawwa (1988) in his book Qawaneen al-Bayt alMuslim has indicated ten types of disciplines or family laws that need to be digested and 
closely related to each other starting from the law of hygiene to the law of entry and exit house. This work is very interesting because the author does not narrow the scope of the family to the household alone but includes the surrounding community such as neighbours, friends, relatives and guests as part of the family.

A more complete and comprehensive study of the Islamic family system can be traced in the book Tarbiyyah al-Awlad fi al-Islam written by 'Ulwan (2008). This work has proved how Islam has a perfect education system as well as elements of well -being. Among others, in the work he has discussed in detail the concept of education in the Muslim family which it is starting before the construction of the marriage bond again. Similar writings exist in other children's education books such as the book Tuhfat al-Mawdud bi Ahkam al-Mawlud by al-Jawzi (2009) and Manhaj al-Tarbiyyah al-Nabawiyyah li al-Tifl by (Suwayd, 1988).

In the context of the creating a perfect household, there are many modern writings that discuss this matter such as al-Islam wa al-Usrah al-Sa'idah written by Ibrahim (1983), Usul alTarbiyyah al-Islamiyyah wa Asalibuha written by al-Nahlawi (1986), Panduan Munakahat written by al-Haj (t.th), Memasuki Gerbang Perkahwinan written by the Review Committee of the Department of Islamic Development Malaysia (2008) and Challenges, Cabaran, Halangan dan Pendekatan Strategik dalam Pembentukan Keluarga Bahagia written by (Hashim, 2002).

\section{Objective}

This paper aims to discuss the construction of the i-Kasih module in support of the families of opiate addicts. In addition, this paper will also evaluate the effectiveness of the i-Kasih module on family social support to opiate addicts.

\section{Methodology}

This study uses quantitative methods and with the study design being a survey study. Data were collected using a questionnaire form adapted from the social support questionnaire by Syazrah et al. (2017). The questionnaire contained four sections measuring the forms of family social support provided to opiate addicts. Questionnaires were distributed before the respondents joined the module and after a month of following the i-Kasih module program. Respondents consisted of 35 participants of the i-Kasih module who successfully completed the final module testing completely. Module participants are family members consisting of mothers, fathers, spouses, siblings, grandparents to opiate addicts in the district of Kuala Terengganu. However, this study did not involve families of opiate addicts who participated in the program while the module was still in the development stage. The selection of respondents based on the sample selection method is purposeful where the respondents are selected based on the ability of the respondent to provide information to the researcher and permission to be interviewed (Matthews \& Ross, 2010). Then, the data were analysed using t-test analysis to obtain the differences between pre-test and post-module tests.

\section{Findings and Discussion}

The i-Kasih module is not only built based on findings in the field, but also tested for its effectiveness. The purpose is for the module to be proven effective and able to give a holistic impact to module participants. Meanwhile, the module evaluation was able to assess changes in family support for opiate addicts. 


\section{Development of Kasih Family Module (i-Kasih)}

The development of the Keluarga Kasih $i$-Kasih module is an initiative to produce a support module for families of opiate addicts. This module takes five years in the field involving two phases. The first phase is the first three years involving the collection of data from interviews and questionnaires as well as the construction of a module framework. Programs involving addicts were also held to obtain inputs on form of family support from the perspective of the opiate addicts themselves. Interviews with agencies and communities were also conducted to obtain the reality of family involvement from the agency's experience and family community management. These findings form the framework for the i-Kasih module and further strengthened by the literature. In this phase, the draft modules are tested on different respondents to get feedback on the content and implementation methods that suit the needs of the participants.

The second phase involves the last two years specifically for testing and evaluation of the effectiveness of the module. The i-Kasih module was tested in two module test programs involving different groups of respondents from the respondents in the first phase. In this phase the module is more focused on testing appropriate implementation methods as well as evaluating the effectiveness of the module in improving family support. This module also seeks the consulting services of module experts in both phases to ensure that the construction of this module complies with the principles of an impactful module.

\section{I-Kasih Module}

The i-Kasih module contains seven units, each with a different focus to meet the social support needs of the family involving emotional, spiritual, informational and instrumental. Each unit is arranged according to the development of family needs when managing opiate addicts in their respective families. Modules are implemented in a variety of delivery methods including interactive discussions, group exercises (LDK), video screenings and games.

\section{- Ziarah Kasih}

This unit is important in ensuring family involvement in the program and building good relationships between family members and researchers. Sharing these experiences requires trust from family members. This unit is an independent unit as appropriate before the module is implemented.

\section{- Bicara Kasih}

This unit aims to provide awareness, motivation and guidance towards building a prosperous family according to Islam, challenges in family life as well as methods of solving family problems according to Islam.

\section{- Curahan Kasih}

This unit aims to channel rehabilitation inputs involving clinical and alternative treatments, in accordance with the preferences of families in Terengganu.

\section{- Ujian Kasih}

This unit aims to expose families to the importance of having resilience, problem -solving skills with collective effort as a measure of facing a test. 


\section{- Talian Kasih}

This unit aims to maintain existing relationships as well as demonstrate the ongoing concern by the research team about the problems and stresses faced by the families involved. This unit is also implemented as a method for monitoring the family.

\section{- Simpulan Kasih}

This unit aims to provide an understanding that addiction rehabilitation plan must be followed by courage to act as well as family collaboration collectively and comprehensively.

\section{- Hamparan Kasih}

This unit aims to ensure that the family relationship between participants and addicts is always close and build participants' awareness of social support networks in helping family members involved with addiction.

\section{Effectiveness of $\mathrm{i}$-Kasih Module}

Effectiveness evaluation of the i-Kasih module is important to ensure that the i-Kasih module can be applied to all forms of families with addiction problems. The i-Kasih module measurements used the same questionnaire for pre-test and post-test. The pre-test for the iKasih module is done before the participants follow the module. This is done to assess the situation of the participants before attending the module and can assess the changes that occur after attending the module. The following Table 1 shows the mean values obtained in the pre-test.

\begin{tabular}{lllll}
\hline \multicolumn{5}{c}{ Table 1: Support Difference in i-Kasih Module's Pre-test } \\
\hline & $\mathrm{N}$ & Min & S. P & Level \\
\hline Emotional Support & 35 & 6.54 & 1.688 & Moderate \\
Family Social Support & 35 & 6.02 & 1.574 & Moderate \\
Information Support & 35 & 4.7 & 1.996 & Moderate \\
Spiritual Support & 35 & 4.39 & 1.961 & Moderate \\
Instrumental Support & 35 & 3.7 & 1.618 & Moderate \\
\hline
\end{tabular}

Descriptive analysis using SPSS found that emotional support (mean $=6.54, \mathrm{~S} . \mathrm{P}=$ 1.688) was the highest support given before following the i-Kasih module. Second, family social support (mean $=6.02, \mathrm{~S} . \mathrm{P}=1.574)$ and followed by information support (mean $=4.7$, $S . P=1.996)$, spiritual support (mean $=4.39,1.961)$ and lastly instrumental support (mean $=$ 3.7, S. $\mathrm{P}=1.618$ ). All of these social supports were given moderately by respondents to opiate addicts. Mean values and levels of social support are as shown in table 2 below.

\begin{tabular}{cc}
\hline \multicolumn{2}{c}{ Table 2: Mean and Support Level } \\
\hline Mean Value & Level \\
\hline $0-3.33$ & Low \\
$3.34-6.66$ & Moderate \\
$6.67-10$ & High \\
\hline
\end{tabular}

Social support among respondents was found to increase after attending the i-Kasih module. Based on the following table 3 shows the mean value and level of forms of social support. 


\begin{tabular}{lllll}
\hline \multicolumn{5}{c}{ Table 3: Support Difference in i-Kasih Module's Post-test } \\
\hline & $\mathrm{N}$ & Mean & S. P & Level \\
\hline Emotional Support & 35 & 8.89 & 1.665 & High \\
Family Social Support & 35 & 8.87 & 1.403 & High \\
Information Support & 35 & 8.11 & 1.808 & High \\
Spiritual Support & 35 & 7.67 & 2.159 & High \\
Instrumental Support & 35 & 7.09 & 1.855 & High \\
\hline
\end{tabular}

After attending the i-Kasih module, there was an increase in respondents' efforts to channel social support. The highest support, family social support (mean $=8.89$, S.P $=1.665$ ) which involved understanding the important role that respondents had to play. Second, emotional support (mean $=8.87, \mathrm{SP}=1.403$ ) followed by information support (mean $=8.11, \mathrm{SP}=1.808$ ), spiritual support (mean $=7.67, \mathrm{SP}=2.159$ ) and lastly instrumental support (mean $=7.09, \mathrm{SP}$ $=1.855$ ). All the social support that has been given is at a high level. Briefly the differences of pre-test and post-test are shown in chart 1 below.

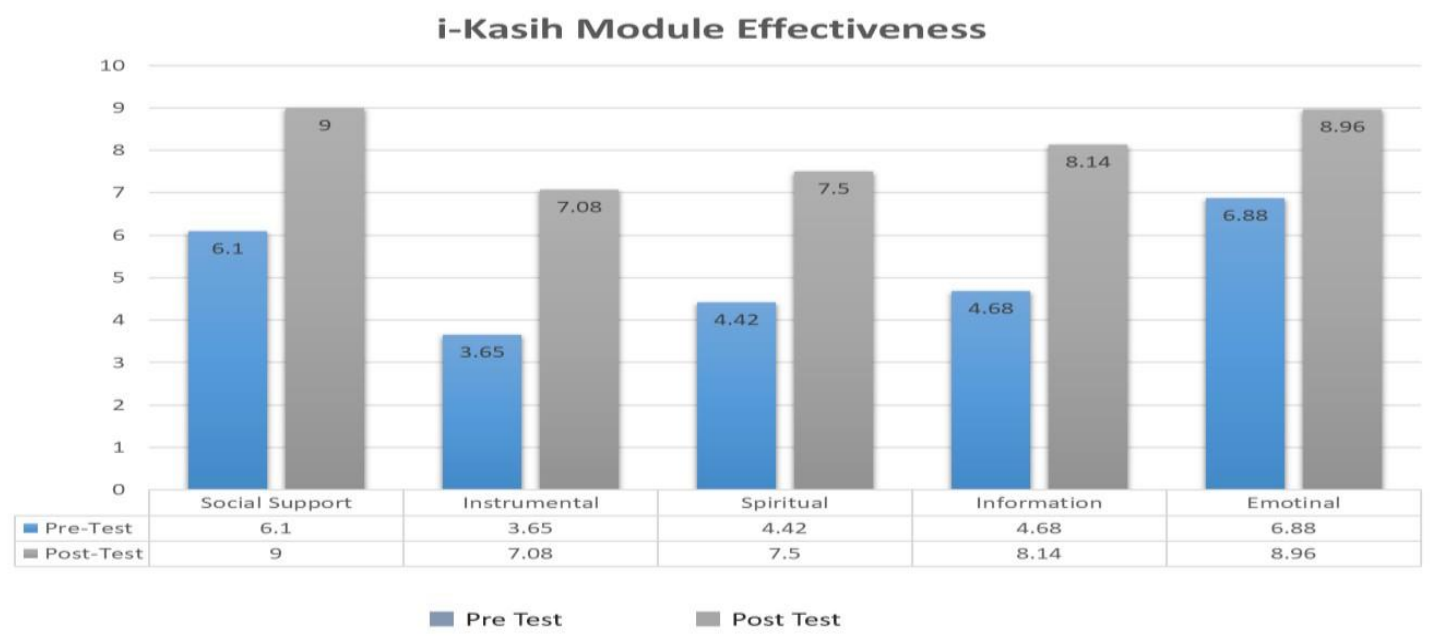

Chart 1: Differences in Mean Values in Pre-Test and Post-Test of i-Kasih Module

An increase was shown in all forms of social support, indicating the i-Kasih module was effective in supporting the families of opiate addicts. This moderate to high level increase can also be understood as respondents who have accurate information are motivated to assist opiate addicts in pursuing rehabilitation programs.

Family social support was in the second highest position in the pre-test but has shown changes to the first place in the post-test. This implied that respondents have understood and taken responsibility for assisting the rehabilitation of addicts. This awareness is key to the success of other support given to addicts. The reason being, without the willingness of the family to assist in rehabilitation, rehabilitation efforts either within or outside the institution will experience difficulties. Next, emotional support was the highest support given by the family before but still at a moderate level. Emotional support is shown through acceptance, involvement in the recovery process and appreciation of the efforts made by the addict to recover. The role of emotional support serves to build the self -confidence of the addict thus preventing the feeling of stress felt by the addict. 
Family social support and emotional support had high scores due to family relationship factors. This relationship becomes a major strength in attracting families equally involved in all rehabilitation programs. However, both of these supports can be threatened by fatigue, stress and limited knowledge while this recovery requires commitment over a long period of time. Therefore, family involvement with the i-Kasih module is able to help respondents maintain both of these supports.

The information support provided to addicts also changed, with respondents admitting not only advising, but also seeking information and recommending rehabilitative treatment to respondents. Although emotional support is often requested by addicts however, informational support is often accessed by addicts without involving family (Flickinger et al., 2016). Thus, if the family is able to be supplied with knowledge, the addict no longer feels alone and loses guidance. It is also able to overcome the constraints that families often face, namely the challenge of knowledge.

As for spiritual and informational support, a support that is given less attention by families, is now beginning to be given attention. The i-Kasih module is a spiritual-based module and it has changed the respondents to place more emphasis on the practice of fardhu ain and act as a role model to practice the practice at home. Meanwhile, respondents were also more proactive in providing instrumental support by helping addicts rebuild relationships with the community, get jobs and finance. This instrumental support is important to help addicts rebuild lives without relying directly on family. This instrumental support however still remains the lowest given by the respondents compared to other forms of support.

\section{Conclusion}

The changes shown by the respondents after participating in the i-Kasih module mean that families need to be helped and guided in order to get involved in rehabilitation programs to help addicts. Efforts to involve families in the rehabilitation of addicts need to take a step back by assessing the needs and willingness of families to participate in the lengthy rehabilitation process.

\section{Appreciation}

This project is funded under the Nic Research Grant Scheme (NRGS-KPM) UniSZA/NRGS/2013/RR057, Sultan Zainal Abidin University (UniSZA), Kuala Terengganu. The highest appreciation to the Department of Education Malaysia, Ministry of Education Malaysia, Marang Prison Department and Sultan Zainal Abidin University for the assistance given to this project.

\section{References}

Kamarulzamana, A., \& McBrayer, J. L. (2015). Compulsory Drug Detention Centers in East and Southeast Asia. International Journal of Drug Policy 26 S33-S37.

Yahaya, A., Najib, M., Ghaffar, A., \& Badrulzaman. (2006). Persekitaran Keluarga dan Kesannya Terhadap Tingkah Laku Devian Remaja. Retrieved from http://eprints.utm.my/2354/1/AziziYahaya_Persekitaran_Keluarga_dan_Kesannya. pdf Dedi Afandi, Fifia Chandra dan Lilik Kurniawan. (2009).

Ghazalli, F. S. M., Ghani, N. A., Abdullah, B., Chik, W. M. Y. W., \& Zakaria, M. A. (2018). Cabaran Keluarga dalam Membantu Pemulihan Penagih Opiat. Asian People Journal (APJ) eISSN: 2600-8971, 1(1), PP 01-11. 
Ghazali, F. S. M., Abdullah, S. N. F., Juahir, H., Ghani, N. A., \& Azizi, M. A. (2017). Assesment by Multivariate Analysis of Family Support towards The Opiate Dependent: A Case Study in Terengganu. Journal of Fundamental and Applied Sciences. 9(2S), 238-255.

Ibrahim, F., Zakaria, E., Nen, S., Sarnon, N., \& Saim, N. J. (2014). Pengguna Dadah Wanita di Malaysia: Pengalaman Penagihan dan Hubungan Kekeluargaan. Jurnal Teknologi (Sosial Sciences) 6(1), 17-25. EISSN 22895434.

Fauziah \& Kumar, N. (2009). Factors Effecting Drug Relapse in Malaysia: An Empirical Evidance. Asian Social Science Journal, 5(12).

Flickinger, T. E., DeBolt, C., Waldman, A. L., Reynolds, G., Cohn, W. F., Beach, Ingersoll, M., \& Dillingham, R. (2016). Sosial Support in a Virtual Community: Analysis of a ClinicAffiliated Online Support Group for Persons Living with HIV/ AIDS. AIDS and Behavior. DOI 10.1007/s10461-0161587-3.

Alavi, K., Sail, R. M., Idris, K., Samah, A. A., \& Chan, C. (2011). Keperluan Sokongan Emosional Dalam Kalangan Anak Dewasa Yang Menjaga Warga Tua. Jurnal e- Bangi, 6(1), 102114.

Luther, K. (2015). Examining Sosial Support Among Adult Children of Incarcerated Parents. Family Relations 64: 505-518 DOI:10.1111/fare.12134.

Matthews, B., \& Ross, L. (2010). Research Methods: A Practical Guide for the Sosial Sciences. Edinburgh Gate: Pearson E.

Hassan, S. A., \& Khairuldin, W. M. K. F. W. (2020). Research Design Based on Fatwa Making Process: An Exploratory Study. International Journal of Higher Education, 9(6), 241246.

Said, N. A., \& Khairuldin. (2017). Freedom of Speech in Islam and its Connection with Street Demonstrations. International Journal of Academic Research in Business and Social Sciences, 7(4), 122-129.

Khairuldin, Embong, A. H., Anas, W. N. I. W. N., Ismail, D., Ibrahim, I., \& Fauzi, N. (2017). Freedom of Speech: A Comparative Study between Islam and Malaysian Laws. International Journal of Academic Research in Business and Social Sciences, 7(2), 2222-6990.

Ibrahim, I., \& Khairuldin. (2017). Fatwa as a Medium Da'wah: Studies on the Role of Mufti as a Preacher. International Journal of Academic Research in Business and Social Sciences, 7(4), 10-18.

NOVA recovery. (2016). The Power of Family in Addiction Recovery. Retrieved from http://novarecoverycenter.com/wpcontent/uploads/2016/11/novarecoverycenter.c om_t he_power_of_family_in_addiction_therapy.pdf.

Lamin, R. A. C., Othman, C. N., \& Othman, N. (2013). Behavioral Study on Methadone Maintenance Therapy Awareness amongst Public in Malaysian Hospital. Procedia Sosial and Behavioral Sciences, 101, $159-169$.

Min, R. M., Abdullah, M. N., Omar, N. E. (2012). Keperibadian Dan Sokongan Sosial Penghuni Puspen: Implikasi Terhadap Program Pemulihan. Jurnal Kemanusiaan 20 ISSN: 16751930.

Ghani, S. A., Zamani, Z. A., Rahman, R. M. A., Zainal, A., \& Sulaiman, W. S. W. (2008). Kefungsian Keluarga dan Hubungannya dengan Keyakinan Diri Pengguna opiat. Jurnal $A A D K$.

Schafer, G. (2011). Family Functioning in Families with Alcohol and Other Drug Addiction. Sosial Policy Journal of New Zealand Te Puna Whakaaro. (37), 1-17.

Snapp, S. D., Watson, R. J., Russell, S. T., Diaz, R. M., \& Ryan, C. (2015). Sosial Support Networks 
for LGBT Young Adults: Low Cost Strategies for Positive Adjustment. Family Relations 64, 420-430 DOI:10.1111/fare.12124.

Sullivan, E., Mino, M., \& Nelson, K. (2002). Families as a Resource in Recovery from Drug Abuse: An Evaluation of La Bodega de la Familia. Retrieved from https://www.ncjrs.gov/pdffiles1/nij/grants/195087.pdf.

Rahman, W. R. A., Dzulkifli, M. A., Dawood, S. R. S., \& Mohamad, M. (2009). Sokongan Sosial kepada Pengguna opiat Dadah dalam Kalangan Kaum Melayu, Cina, dan India di Malaysia. Jurnal AADK. 